\title{
Cash flow statement: management tool or statutory requirement?
}

\author{
I.J. Lambrechts \\ Departement Business Management, University of Stellenbosch, Private Bag X5018, Stellenbosch 7599, Republic of South Africa
}

Ontvang Februarie 1993, aanvaar Seplember 1993

\begin{abstract}
The Cash Flow Statement (CFS) had been in use in South Africa since October 1988. It replaced the Statement of Sources and Application of Funds, which had been in use since 1973. In spite of the general acceptance of the benefits of the CFS and its superiority over the Statement of Sources and Application of Funds, there are certain inherent problems. These problems mainly relate to the format of the CFS and its ability to assist in forecasting the survival prospects of an enterprise. In this article the focus is firstly on the formal of the CFS and it is compared with the requirements of other guidelines. A revised format is proposed. It also considers the usefulness of the CFS as a management $100 l$ in financial decision making. Areas of financial decision making which are considered, are financing, capital investment, dividend and pricing decisions. The final conclusion is that although the CFS could be standardized to a large extent, the same does not apply to the calculation of cash flows for financial decision making in different areas.
\end{abstract}

\begin{abstract}
Die Kontantvloeistaat (KVS) is sedert Oktober 1988 in Suid-Afrika in gebruik. Dit het die Staat van Bronne en Aanwending van Fondse wat sedert 1973 in gebruik was, vervang. Ten spyte van die algemene aanvaarding van die voordele van die KVS in vergelyking met die Staat van Bronne en Aanwending van Fondse, is daar tog sekere inherente probleme. Hierdie probleme hou hoofsaaklik verband met die formaat van die KVS en die vermoè om met behulp daarvan dic oorlewingsmoontlikhede van 'n onderneming vooruit te skat. In hierdie artikel word eerstens op die formaat van die KVS gefokus en dit word met die vereistes van ander riglyne vergelyk. 'n Hersiene formaat word voorgestel. Oorweging word ook aan die geskiktheid van die KVS as 'n bestuursinstrument in finansiële besluitneming geskenk. Gebiede van finansiële besluitneming wat oorweeg word, is finansierings-, investerings-, dividend- en prysbepalingsbesluite. Die finale gevolgtrekking is dat alhoewel die KVS in 'n groot mate gestandaardiseer kan word, dieselfde nie van toepassing is op die berckening van die kontantvloei vir finansiële besluitneming in verskillende deelgebiade nie.
\end{abstract}

\section{Introduction}

The Cash Flow Statement (CFS) has been in use in South Africa since October 1988. It replaced the Statement of Sources and Application of Funds (SSAF) which had been in use since 1973 as a statutory requirement of the 4th Schedule of the Companies Act, No. 61 of 1973. The SSAF had some serious limitations. In 1978 Guideline 4.003 was published and it was recommended that a supplementary inflation-adjusted income statement should be published. In research it was pointed out that the income of guidcline 4.003 (later replaced by Guideline AC201) showed a 100\% correlation with cash flow in the absence of real growth (Hamman, 1979: 181-184). Unfortunately this supplementary statement (optional) never received proper acknowledgement. Guideline AC118 on cash flow information stated, however, that the cash flow information required by the CFS would provide the specified information. The requirement to include the CFS in the annual financial statements has recently been incorporated in the Companies Act.

The CFS focuses on cash flow rather than flows of working capital. Security and financial analysts recently viewed cash flow information as a more accurate yardstick to evaluate debt and dividend-paying ability.

In spite of the general acceptance of the benefits of the CFS and its superiority over the SSAF, there are certain inherent problems. These problems mainly relate to the format of the CFS and its ability to assist in forecasting the survival prospects of an enterprise (Gentry, 1983).

The objectives of this article are twofold: Firstly, it will focus on the format of the CFS as described in AC118, and be compared with the requirements of other guidelines. This analysis will address the statutory part of the topic. A revised format will be proposed. Secondly, the usefulness of the CFS as a management tool in financial decision-making will be investigated. The use of the cash flow concept for different financial decisions will be surveyed. This will prove the wide divergence between cash flow concepts and that the definition varies according to specific circumstances and occasions.

\section{Format of the CFS}

The CFS's to be compared with Guideline AC1 18 are those of the Statement of Financial Accounting Standards No. 95 of the Financial Accounting Standards Board of November 1987 (FASB95); the International Accounting Standards Committee Exposure Draft 36 of July 1991 (ED36), and the Accounting Standards Board Financial Reporting Standard No. 1 of Scptember 1991 (FRS1). The main features of AC118 will be emphasized and differences with the others pointed out.

AC1 18 is divided into the following sections:

- cash from operating activities divided into:

cash from operations (CFO)

investment income

changes in non-cash components of working capital (NCWC)

- financing costs and taxation

- dividends

- investing activities

- financing activities.

The main points of criticism against this lay-out are the inclusion of investment income under operating activities and the exclusion of the changes in the NCWC from CFO. Investment income does not form part of the operating activities in the case of industrial enterprises. For financial institutions it would form part of CFO. The changes in 
NCWC (stock, debtors and creditors) definitely form part of CFO because a change in any of these components results in a change in cash arising from the operating activities in the income statement. The main confusion in $\mathrm{AC} 118$ arises from the heading 'cash from operating activities' and 'CFO'. Confusing terminology like 'cash retained from operating activities', 'cash generated by operating activities', and 'cash available from operating activities' are used and they all have different meanings and calculations (sce Appendix 1 for a summarized version of Guideline $\mathrm{ACl18}$ ).

FASB95 recommends only three sections, i.e. CFO, investing and financing activitics. CFO has no subsections and includes investment income, interest, dividends and taxation paid. The ultimate balance of this section is referred to as 'net cash provided by operating activities'. It is, however, interesting that three out of seven members differed on the inclusion of interest and dividends received and interest paid, as part of CFO. The first two items should be classified as cash inflows from investments and the latter as part of financing activities.

ED36 also recommends three sections. These items are CFO, investing and financing activities. Cash flows from operating activities has, however, three subsections, i.e.:

- operating income before changes in the NCWC;

- CFO after changes in NCWC; and

- net cash provided by operating activities.

Investment income is taken into account in calculating the third component as is the case with interest and income tax. It is explicitly stated that there is no consensus regarding the classification of interest paid and investment income. An alternative is suggested in the text, i.e. that it should be part of financing activities. An interesting point is that dividends paid form part of financing activities as in FASB95 (not so in the case of $\mathrm{AC118}$ ). The terminology is just as confusing as in the case of $\mathrm{AC} 118$.

FRS1 suggests five sections, i.e.

- operating activities;

- retums on investments and servicing of finance, i.e. investment income and dividends and interest paid;

- taxation;

- investing activities; and

- financing activities.

The calculation of operating activities is very clear and includes NCWC because of the direct method which is suggested. The confusion which exists with the other guidelines does not exist here, mainly as a result of more sections and no confusing terminology.

Certain other points which could be of value in an attempt to improve the reporting standards in South Africa, are raised in all the guidelines except in Guideline AC118. Much emphasis is placed on the direct method of compiling the CFS. It appears as if the other three guidelines prefer the direct method. FASB95 is not so explicit in its preference and makes provision for those who prefer the indirect method. Reconciliations between net income and CFO should be given. A minority opinion (two out of seven) was expressed against the indirect method because the direct method provides a more informative description of the operating activities. ED36 encourages enterprises to use the direct method but it permits the indinect method where substantial costs will have to be incurred. FRS1 also prefers the direct method but, in cases where high costs are incurred, it recommends the indirect method. In all its examples the direct method is used. Reconciliations are, however, also necessary. AC118 avoids the subject of direct or indirect methods completely and uses only the indirect method.

The gross rather than the net approach is recommended by FASB95, ED36 and AC118. This means that gross amounts of cash receipts and cash payments during a period is more relevant than information about the net amounts of cash receipts and payments. FASB95 mentions that in the case of certain items, tumover ratios are quick, the amounts are large and the maturities are short and in these cases a net approach could be followed. Reference is made of cash receipts and payments pertaining to investments, loans receivable and debt with maturities of three months or less. ED36 also makes provision for certain exemptions for the investing and financing functions of a financial institution. $\mathrm{AC}$ 118 only mentions that net amounts may be used where disclosure of gross amounts is inappropriate or impracticable. FRS1 states that either the net or gross basis may be used.

\section{Other points of interest}

Other points of interest which could be considered in an endeavour to improve the lay-out of the CFS are referred to in one or more of these statements. They are the following:

\section{Cash flow per share}

FASB95 mentions that cash flow per share should not be reported (par. 33). The motivation is that neither cash flow nor any component thereof is an indication of an enterprise's performance, as reporting a figure per share might imply. This could be a valuable variable but the problem lies mainly in the calculation or definition of cash flow. If a suitable definition could be used in a standardized way (like earnings per share), this could be a meaningful figure to compare with eamings per share.

\section{Direct and indirect approach}

ED36 encourages the disclosure of cash payments that represent increases in operating capacity separately from cash payments required to maintain the operating capacity (par. 48[a]). AC118 encourages the same differentiation (par. 27). FASB95 does not require this disclosure because of the implementation difficulties. FRS1 recognizes these difficulties but considers it as optional for entities that find it useful.

\section{Amount of unused borrowing facilities}

A further optional item in ED36 is the amount of unused borrowing facilities available for future operating activities and to settle capital commitments (par. 48[b]).

\section{Cash flow information for different segments}

ED36 also encourages the disclosure of cash flow information for different segments (industries) and geographical areas (par. 48[c]). 


\section{Exemption of small reporting entities}

FRS1 exempts small reporting entities from the requirement to include a CFS as part of their financial statements with certain exceptions.

\section{Proposal for a revised AC118}

Guideline $\mathrm{AC} 118$ was a major improvement on the requircment of the Companies Act to publish certain information on sources and application of funds. Its implementation was long overdue and the recent change of the Companies Act to make provision for this improvement has to be welcomed. The format of the CFS could, however, be changed to make it a more relevant, meaningful, accurate and representative statement. When considering changes, the following aspects have to be addressed:

1. Less confusing terminology, especially in calculating CFO and in differentiating between operating and financial income (interest and dividends).

2. More sections to eliminate or reduce the possibility of confusing classification and meaningless totals/subtotals.

3. Changes in NCWC should be part of CFO (this shortcoming could possibly be due to the use of confusing terminology).

4. A consideration of the benefits of the direct method to establish whether the additional trouble and cost involved would facilitate decision-making.

5. Should exemptions be allowed to follow the net approach? If yes, it would reduce the value of the CFS, especially for the external analyst.

6. Additional matters include the calculation of cash flow per share, the differentiation between expansion and replacement, the differentiation between financial and capital investments, and the provision of segmental and geographical information.

In Appendix 3 a revised pro forma CFS based on the figures in Guideline $\mathrm{AC1} 18$ is suggested. The important features of the revised format are:

1. There are four main sections, i.e. NCTA (net cash from total activitics), capital investments, financial investments and financing activities. NCTA has two subtotals, i.e. CFO and CTA (cash from total activitics). The CFO relates to the operating income in the income statement, the CTA to EBIT, and NCTA to retained income. This neat sinchronization with the income statement improves the meaningfulness, reliability and comparability of figures and variables between different enterprises.

2. A differentiation is made between capital and financial investments. For an industrial enterprise there is no relationship between these two catagories of investments. The first priority should be to maintain and expand the existing facilities to satisfy the demands of the consumers. This could be done by means of internal or external expansion through mergers and take-overs. Sccondly, if the opportunity arises to invest in debentures, loans or shares of other institutions, this would involve a separate and completely different decision for an industrial enterprise.
3. No differentiation is made between replacement of, and additions to, fixed assets. This would have been valuable information for analytical purposes. The problem is that it is often difficult to differentiate between replacements and expansions. A major expansion project often involves a substantial replacement component. As a result of the unreliability of the differentiation and the meaninglessness of the result, most enterprises do not endeavour to split these components.

4. Changes in working capital resulting from expansions are omitted. The intention is certainly not to include the cash، components of working capital under this item. The NCWC is included under CFO and the change could be as a result of a change in volume, the inflation rate and a change in working capital efficiency. Likewise changes in all other items under CFO could be as a result of changes in these contributing factors. Why the discrimination? The change in NCWC is a reflection of an adjustment required to reconcile the net income figure with CFO. Excessive changes (i.e. higher than the volume change) could possibly be shown under capital investment activities. The three guidelines, excluding $\mathrm{AC} 118$, also do not refer to this item.

5. The new format is based on the indirect method. The main difference between the direct and the indirect method is that CFO amounts to the difference between cash receipts from consumers and cash paid to suppliers and employees in the direct method. There is consequently no need to calculate NCWC. There is no reason why the direct method should be excluded. The final result would be the same, especially if a reconciliation between the income figure (operating income) and CFO or between CTA and EBIT is given.

6. The gross method should be prescribed and no possibility for net figures should be created. The net method could result in new borrowings and the redemption of existing borrowings bcing netted. This would deprive the financial analyst of valuable information because redemplion of existing borrowings form part of the total cash requirements of the enterprise which should be financed.

The other points discussed above could be treated as supplementary items and would supply valuable information to assist the financial analyst in his decision-making. This includes the calculation of cash flow per share, the amount of unused borrowing facilities, and the disclosure of cash flow information for different segments and possibly geographical areas.

The requirement to prepare a CFS should, however, apply to all enterprises. Small reporting entities should not be exempled as suggested by FRS1. To compel all enterprises to compile a CFS would force the management to relate decision-making to the effect on the CFS. The need for this is even higher in the smaller enterprise.

\section{CFS as a management tool}

Introduction

Cash flow figures are often recommended for management decisions because of the shortcomings of net income figures. These shortcomings stem mainly from the calculation of net 
income which is to a very large extent a function of the valuation of stocks and fixed assets (Mackintosh, 1981: 127-133). Often net income calculated on a monetary basis is preferred to the real basis. Cash flow figures in the CFS incorporate the income statement and the balance sheet, and automatically include the higher cost of fixed assets and stock as a result of inflation.

The first incorporation of cash flow figures into management decision-making was in the field of capital investments. Cash benefits were traditionally calculated as net income (before interest) after tax plus depreciation, and the present values were compared with the present values of the investment amounts. This calculation does, however, not apply to other financial decisions. Even in evaluating capital investments, certain refinements took place as well as certain justifiable deviations under special circumstances (Giacomino \& Miclke, 1988: 54-58).

The objective of this section is to consider the calculation of relevant cash flows to be used to improve financing, capital investment, dividend and pricing decisions (Stancill, 1987: 87-93.). These calculations will be related to, or defined in terms of, the revised format of the CFS. The CFS has a further application and that is as a predictor of corporate failures. This section will, however, focus on the use of the CFS as an internal management tool on a continuous basis rather than its use for external analysts. The final conclusion will be that although the CFS could be standardized to a large degree, the same does not apply to the calculation of cash flows for financial decision-making in different arcas (Casey \& Bartc7ak, 1984: 61-66).

\section{CFS and financial decisions}

One of the most important financing decisions is the ratio of debt to equity to be used. Normally this figure is used in a balance shcet context. This is a very insensitive measure because of accumulation and does not immediately signal a sudden change. This shortcoming could be overcome by calculating internally generated funds (IGF) and comparing this figure with total capital requirements (TR), where

TGF = NCTA

TR = Capital investments + financial investments + repayment of borrowings (or redecmable preference shares).

This ratio does, however, not relate to the equity to total capital ratio. A more relevant ratio would be

IGF + Equity raised: TR.

Another ratio in evaluating how much debt an enterprise can service is to determine its interest coverage and the debt service coverage ratio. The first in a cash flow context equals:

CTAVFinancing costs

and the latter:
CTA - taxation/(Financing costs $(1-t)+$ repayment of borrowings).

The above calculations should not only be done on a historical basis but also for the future. Long-term planning in this respect is absolutely vital.

A further application of cash flow figures is to evaluate and rank different forms of financing. The cash flows (payments) in these instances would include interest (after tax) and capital flows.

\section{CFS and capital investment decisions}

The cash flow figures to be used in evaluating capital investments vary according to the main category of investments, i.e. whether it is internal or external (mergers and take-overs). In the first case the cash benefits equal CFO (after tax) and this figure is related to the net capital investment costs (i.e. after proceeds on disposal after tax). The investment income and financing costs are ignored because the cash flow figures are either discounted at a rate equal to the cost of capital or expressed in an effective rate of return which is compared to the cost of capital. The cost of capital already makes provision for inter alia the cost of debt. Likewise the cash flows of new sources of financing and repayment of borrowings are ignored.

In the case of external capital investments (take-overs) the interest and redemption commitments taken over as a result of the combination should be taken into account because these payments increase the purchasing price. The net cash inflows of the target enterprise would equal CFO (after tax) - financing costs (1-t) - repayment of borrowings or any other cash outflow as a direct result of the take-over.

\section{CFS and dividend decisions}

In formulating a dividend policy it is possible to adopt a cash flow approach, i.e. a policy of residual amounts. The magnitude of the dividends is a function of the financing and the investment decisions. If an enterprise can eam more than its cost of capital, it would be more profitable to invest even the distributable income.

The policy of residual amounts (in terms of income figures) involves that the total investment amounts (capital and financial) are determined by means of feasibility studies. Repayment of borrowings are also taken into account. This is followed by the determination of the equity capital necessary to finance the additional requirements. The undistributed income is firstly used to satisfy the demand for equity capital. If it is insufficient, additional shares will have to be issued and when there is a residual amount, a dividend could be paid.

The problem with the above approach is that the retained income would not balance with the NCTA. It is therefore preferable to follow a cash flow residual approach as follows:

IGF available (IGFA)

Target ratio IGF

TGF required (IGFR)

$$
\begin{aligned}
= & \text { CTA }- \text { financing } \\
& \text { costs }- \text { taxation } \\
= & \text { TIGF } \\
= & \text { TIGF } x \text { TR } \\
= & \text { IGFR }- \text { IGFA } \\
= & \text { Total capital requirements }
\end{aligned}
$$$$
\text { where TR }
$$ 
If $\mathrm{EC}$ is a positive figure it would indicate that there is no cash available for dividend payment and additional ordinary shares will have to be issued. This approach is preferred to the traditional one based on income figures. A strict application of this policy will of course result in dividends fluctuating considerably, with the disadvantages attached to such fluctuations. To overcome this problem a cash flow forecast over a longer period could be used.

$A$ ratio which could be used to evaluate the risk associated with a specific dividend policy is the dividend coverage ratio in terms of the CFS which is

equal to: $\frac{\text { NCTA before ordinary dividends paid }}{\text { Ordinary dividends paid }}$

The important aspect in using the CFS as a basis for the dividend decision is the definition of cash flow. The cash flow component is after payment of interest and taxation, i.e. NCTA before ordinary dividends paid.

\section{CFS and pricing decisions}

Pricing decisions are often made by referring to the competitive situation but with the ultimate aim of achicving a satisfactory profitability ratio. In price regulated industries this decision is often made by simulating a competitive environment and basing prices on a profitability ratio being either the profitability on total capital employed or on equity capital.

Calculations based on profitability are subject to serious disadvantages, inaccuracies and arbitrary decisions. The most important problems centre around the valuation of stock and fixed assets as well as exactly which items to include in the capital base. In spite of these deficiencies the profitability method is widely used.

Another method which is becoming more popular is the price-capping method. This method is based on the Consumer Price Index (CPI) and is calculated as CPI $-\mathrm{X}$ where the $X$ is a specific percentage applicable to an industry. The magnitude of $X$ is often based on arbitrary factors and is quite often the result of political decisions.

The method of price-capping is a relatively simple one. In countries with a high inflation rate there is a built-in accelerator if it is used for a number of services or products. Improvement in productivity is not passed on to the consumer if it is not accounted for in the $X$ factor. It will also inhibit investment in large capital programmes and keeping pace with technological improvements because of inadequate income.

A well-known example of a cash flow approach for tariff determination appeared in the Repon of the Commission of Enquiry into Electricity Supply. The Commission referred to this method as the income cover approach. The income cover calculates the ratio of:

$\frac{A}{B+C}$

where

A = Cash component of operational income, mainly operating income plus depreciation (or CFO excluding the changes of NCWC in the new format for the CFS).

$B=$ Interest based on year-end debt and present interest rates.

$\mathrm{C}=$ Redemption charge for outstanding debt at end of year based on a 20-year redemption period and a specified interest rate.

The income cover method is basically a coverage ratio for fixed obligations based on cash flows. This formula was intended to be applied to Eskom which does not pay tax or dividends. In terms of the proposed format for the CFS the formula can be restated as

NCTA excluding changes in NCWC plus financing costs

$$
\text { Interest plus redemption of debt. }
$$

The shortcomings of this approach are mainly the exclusion of changes in NCWC and investments. To overcome these shortcomings a cash flow pricing approach could include the following steps/calculations:

1. Determine TR.

2. Deduct new loans to replace redeemed loans to get the net TR.

3. Calculate IGFR of the net TR.

4. Deduct NCTA to calculate the shortfall.

5. The shortfall expressed as a percentage of the present sales income gives the tariff/price adjustment percentage.

This method could also result in wide fluctuations from year to year. It would therefore be necessary to make a medium to long term CFS forecast to even out the fluctuations in order to achieve the long term objective of the enterprise.

\section{Summary and conclusions}

The format proposed for the CFS shows certain definite advantages/improvements over the one of $\mathrm{AC118}$. Firstly, the classification and terminology is in line with general practice and considerably improves the lay-out and interpretation. CFO does include the changes in NCWC which is in line with the guidelines that were investigated. Secondly, the subtotals of NCTA (internally generated funds) relate directly to a specific subtotal in the income statement and this would improve financial decision-making. Thirdly, an additional section is proposed to emphasize the difference between capital and financial investments. Capital investments carry a higher priority for an industrial enterprise than financial investments. Other possible improvements include the elimination of the option to calculate net figures under certain circumstances and the possibility to follow the direct approach.

The CFS in its revised format should serve as a management tool in financial decision-making. Financial decisionmaking in the past was to a very large extent based on net income and balance shect figures with their inherent shortcomings. The CFS and especially a forecast of the CFS, 
should be one of the most important financial decisionmaking tools. The revised format with its improved lay-out and more logical classification would contribute to better interpretation and evaluation. The CFS as such would contribute to decision-making in respect of financing, capital investments, dividends and pricing.

The major problem in using the CFS as a management tool is to relate the correct CFS item (variable) to a specific financial issue. In summary, the following guidclines could be given:

1. IGF = NCTA.

2. $\mathbf{T R}=$ Capital investments + financial investments + repayment of borrowings (including redemption of preference shares).

3. IGF + new equity: TR and IGF:TR are useful solvability indicators.

4. CTA/interest and CTA after tax/(interest) after tax + repayment of borrowings are useful coverage ratios.

5. There is a difference between the cash flow used to evaluate internal and external capital investments. In the first case interest payable is excluded from cash flow while in the latter interest (and redemptions), being the responsibility of a target company which has been taken over, should be included.

6. In following the residual approach based on cash flow, IGFA equals NCTA before payment of dividends and IGFR equals TIFG $\times$ TR. The dividend coverage ratio equals NCTA before payment of dividends to dividends paid.

7. The IGFR minus the NCTA gives the shortall in cash flow which should be recovered by means of price increases if the cash flow method is used for pricing decisions.

The revised format of the CFS combined with the correct CFS variable(s) for a specific financial decision would contribute to improved financial decision-making.

\section{References}

Accounting Standards Board (UK): Financial Reporting Standard

No. 1. Cash Flow Statements. Scptember 1991.

Act to consolidate and amend the law relating to companies; and to provide for matters incidental thereto. No 61, 1973.

Amendment to the Companies Act. 1992.

Casey, C.J. \& Barczak. N.J. 1984. 'Cash flow - it's not the bottom line', Harvard Business Review, July-August: 61-66.

Commission of Enquiry into Electricity Supply in the Republic of Soush Africa. Report: October 1984 (Chairman: WJ. de Villiers).
Gentry. J.A. 1983. Funds flow components as predictors of corporale bankrupicy. Faculty working paper No. 964. College of Commerce and Business Administration. Illinois.

Giacomino, D.E. \& Mielke, D.E. 1988. 'Using the statement of cash fow to analyse corporate performance', Management Ac. counting. May: 54-58.

Hamman. W.D. 1979. 'SA Guideline 4.003 and cash flow', The Sowh African Chartered Accouneant. May: 181-184.

International Accounsing-Standard E36. Proposed Statement. Cash Flow Statements, July 1991.

Mackintosh. R.GJ. 1981. 'The funds statement', The South African Chartered Accountant, March: 127-133.

Stancill. J.M. 1987. 'When is there cash in cash flow? Getting numbers you can trust', Harvard Business Review. Boston: Harvard University Publishers, pp.87-93.

Statement of Financial Accounting Standords No.95 (USA): Statement of Cash Flows, November 1987.

Statement of Generally Accepled Accounding Practice ACII8 (SA): Cash Flow Information, October 1988.

\section{Appendlx 1 AC118: Cash flow information}

\section{Cash retained from operating activities}

Cash generated by operations

+ Investment income

\pm (Increase)/decrease working capital

Cash generated by operating activities

- Finance costs

- Taxation paid

Cash available from operating activities

- Dividends paid

Cash utilized in investing activities

Investment to maintain operations =

Replacement of fixed assets +

Proceeds on disposal of fixed assets

Investment to expand operations $=$

Additions to fixed assets +

Purchase of subsidiary +

Increase in working capital resulting from expansions

\section{Cash effects of financing activities}

Increase (decreasc) in long-term borrowings

Increase/(decrease) in short-term borrowings

+ Proceeds of rights issue

- Redemption of preference shares

Appendix 2 Comparison between CFS of AC118, FASB95, ED36 and FRS1

\begin{tabular}{|c|c|c|c|}
\hline AC118 & FASB95 & ED36 & FRS1 \\
\hline \multicolumn{4}{|l|}{ Sections } \\
\hline $\begin{array}{l}\text { Number: } 5 \\
\text { Tiales: }\end{array}$ & 3 & 3 & 5 \\
\hline - Cash from operwing activities & $\begin{array}{l}\text { - Net cash provided by operating } \\
\text { activities (CFO) }\end{array}$ & - Cash flow from operating ectivities & - Operating ectivities \\
\hline $\begin{array}{l}\text { - CFO } \\
\text { * Invedimen income } \\
* \text { Chmere in NCWC }\end{array}$ & - Investing activities & $\begin{array}{l}\text { operating income before changes } \\
\text { in NCWC }\end{array}$ & $\begin{array}{l}\text { - Retums on investments and ser- } \\
\text { vicing of finance }\end{array}$ \\
\hline
\end{tabular}


Appondix 2 (continues)

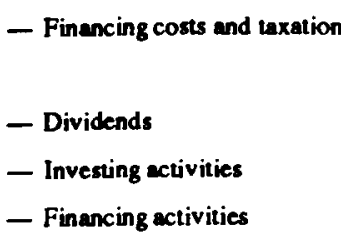

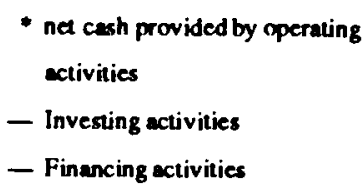

- Investing sctivities

- Financing activities

\section{NCWC:}

\begin{tabular}{|c|c|c|c|}
\hline Excluded from CFO & Included in CFO & $\begin{array}{l}\text { Is distinguishableunder CFO due to } \\
\text { subsections Operating Income before } \\
\text { changes in NCWC and CFO after } \\
\text { changes in NCWC }\end{array}$ & Included under operating activities \\
\hline \multicolumn{4}{|l|}{ Investment income: } \\
\hline Included under operating activities & Included under CFO & $\begin{array}{l}\text { Taken into account when cakulating third } \\
\text { subsection: net cash provided by opera- } \\
\text { ting activities (no consensus on this point; } \\
\text { alternative is financing activities) }\end{array}$ & Under separate heading \\
\hline \multicolumn{4}{|l|}{ Dividends paid: } \\
\hline Shown under separate heading & Included under CFO & Part of financing activitics & $\begin{array}{l}\text { Under separate heading: 'Rewms on } \\
\text { investment and servicing of finance' }\end{array}$ \\
\hline \multicolumn{4}{|l|}{ Direct or indirect method: } \\
\hline $\begin{array}{l}\text { Indirect method used (no reference } \\
\text { to the direct method) }\end{array}$ & $\begin{array}{l}\text { Both are acceptable but the direct } \\
\text { method is suggested (two out of } \\
\text { seven members are against the in- } \\
\text { direct method). Reconciliationsbe- } \\
\text { tween net income and CFO should } \\
\text { be given }\end{array}$ & $\begin{array}{l}\text { Direct is recommended but indirect } \\
\text { is acceptable if the costs of direct } \\
\text { is tom high }\end{array}$ & $\begin{array}{l}\text { Direct mathod is suggested. In- } \\
\text { direct mahod could be used where high } \\
\text { costs will be incurred to follow the } \\
\text { direct approach }\end{array}$ \\
\hline
\end{tabular}

\section{Gross or net:}

Gross, but net anounts may be used where disclosure of gross amounts is impractical and inappropriate
Generally gross is more relevant but net will suffice (especially in the case of certain items where umover ratios are quick, the amounts large and mawrities short)
Gross should be reported as far as possible (certain exemptions are stated)
Fither the gross or net basis may be used

\begin{tabular}{|c|c|c|c|}
\hline $\begin{array}{l}\text { - Requires disclosures of invest- } \\
\text { ment in fixed assets to increase } \\
\text { or maintain operating activities } \\
\text { - Chenges in working capital re- } \\
\text { sulting from expansion are stated } \\
\text { separately } \\
\text { - Term inology confusing }\end{array}$ & $\begin{array}{l}\text { - No distinction between invest- } \\
\text { ments to maintain or increase } \\
\text { operating activities } \\
\text { - Three out of seven members dif- } \\
\text { fered on the treatment of invest- } \\
\text { ment income and dividends paid } \\
\text { - Against reporting cash flow per } \\
\text { share }\end{array}$ & $\begin{array}{l}\text { - Term inology confusing } \\
\text { - Enterprises are encouraged to } \\
\text { distinguish between cash flows to } \\
\text { maintain or expand operating activities } \\
\text { - Unused borrowing facilities avialable } \\
\text { for future operating activities or capital } \\
\text { requirements is an optional item } \\
\text { - Cash flow in formation for different } \\
\text { segments and geographical areas } \\
\text { is encouraged }\end{array}$ & $\begin{array}{l}\text { - More sections and less confusing } \\
\text { terminology lead to a more acceptable } \\
\text { statement } \\
\text { - Small entities are exempted from } \\
\text { the requirements to include the CFS } \\
\text { as pert of financial stuements }\end{array}$ \\
\hline
\end{tabular}


Appendix 3 CFS - Revised format

Net cash from total activities

Income before interest and taxation

Depreciation

(Profit)/Loss on disposal of fixed asset

Investment income

(Increasc)/decrease in NCWC

Cash from operations (CFO)

Investment income

Cash from total activities (CTA)

Financing costs

Taxation paid

Dividends paid

Net cash from total activitics (NCTA)
Capital investment activities

Additions to fixed assets (including replacements)

Proceeds on disposal of fixed assets

Purchase of subsidiary

556

(40)

(225)

(649)

1711

225

1936

(380)

(482)

(384)
Financial investment activities

Loans granted

Surplus

(198)

Financing activities

Repayment of long-term borrowings

Increase in short-term borrowings

Proceeds of rights issue

Cash generated/(utiliz.cd) 